\title{
Odo Rigaldus at the University of Paris (c.1220-48)
}

\begin{abstract}
This article is about Odo Rigaldus' stay at the University of Paris. Odo Rigaldus arrived in Paris around 1220 to study the liberal arts and then theology. He was already an advanced student of theology when he took the Franciscan habit like his master, Alexander of Hales, in 1236. Odo remained in Paris as a bachelor then master in theology until 1248. Throughout his years in Paris, he learned from other masters, participated in debates and disputationes, received academic training, studied alongside other students, and trained disciples in his turn. This article presents the training received by Odo Rigaldus, his intellectual activity within the university, as well as the social network which he established during his years in Paris, in order to shed light on the knowledge he acquired and on the clerics and the personalities with whom he was linked during these founding years and whom he met, in some cases, during his episcopate.
\end{abstract}

Only a few traces or references have come down to us relating to the time spent by Odo Rigaldus at the University of Paris. His name figures, among many others, in the Latin MS 15652 in the Bibliothèque nationale de France, which is a collection of reportationes or notes taken by an anonymous student during a course of study on the Sentences or on the Bible in Paris around 1240. ${ }^{1}$ In 1242, with his master Alexander of Hales and two other bachelor students in theology, he composed the Expositio regulae quatuor magistrorum super regulam fratrum minorum. ${ }^{2}$ A number of sermons from this period in Paris can also be identified. ${ }^{3}$ The Franciscan chronicler Salimbene offers these words in praise of Odo's authoritative status in Paris:

There was a brother [called Odo] Rigaldus of the order of Friars Minor and Archbishop of Rouen, who was one of the greatest clerics in the world. This consecrated master was from Paris and read theology for many years in the house of the friars. He was the greatest disputer and a popular preacher. He wrote a work on the Sentences. He was a friend of the King of France [St Louis] and even worked for him when he held the Archbishopric of Rouen. He was admired by many in

1 M.D. Chenu, 'Maîtres et bacheliers de l'université de Paris vers 1240: Description du manuscrit Paris, Bibl. nat. lat. 15652,' Etudes d'histoire doctrinale et littéraire du XIII siècle (Paris: J. Vrin, 1932), pp. 11-39.

2 Expositio Quatuor Magistrorum Super Regulam Fratrum Minorum (1241-1242), ed. L. Oliger (Rome: Edizioni di storia e letteratura, 1950).

3 See below.

Ә OpenAccess. (c) 2021 Nathalie Gorochov, published by De Gruyter. (c))BY-NC-ND This work is licensed under the Creative Commons Attribution-NonCommercial-NoDerivatives 4.0 License. 
the Order of Friars Preachers as in the Order of Friars Minor, of whom he was a member and for whom he became a benefactor. ${ }^{4}$

Odo probably spent at least twenty years at the University of Paris. If one accepts that he was awarded his degree in theology in 1245, then he would have begun studying this subject as a 'secular' student around 1230, after some years studying the liberal arts in the 1220s. The theology programme of study was itself seemingly interminable - averaging fifteen years in length. Initially, Odo would have been enrolled in this course just as a student auditor, then, from perhaps 1235-38 - around which time he entered the Franciscan order - he would have been promoted to the level of bachelor, and subsequently, to master in theology. ${ }^{5}$

The present study will focus solely on the period spent by Odo Rigaldus at the University of Paris, placing it in a wider context, namely, that of the university environment in Paris which must have influenced him. Throughout these years, he listened to the masters there, participated in debates and disputationes, received academic training, studied alongside other students, and trained disciples in his turn. In considering this period, we need to examine the training Odo received, his intellectual activity within the university, as well as the social network which he established during his years in Paris. This will further our understanding of the knowledge he acquired and of the personalities with whom he forged links during these formative years, some of whom he would, in certain cases, encounter again during his episcopate.

\section{Odo Rigaldus as a Student in Paris in the $1220 \mathrm{~s}$}

\section{The Intellectual Context}

In all probability Odo began by studying the liberal arts, in the years $1220-25$. Prior to 1229 , teaching in the faculty of arts in Paris was limited essentially to grammar, logic and moral philosophy, as is testified by the writings authored by the masters

4 Salimbene of Parma, Chronica, ed. G. Scalia (Bari: G. Laterza, 1966), vol. II, p. 656: 'Erat autem frater Rigaldus ex ordine fratrum minorum et Rotomagensis archiepiscopus et unus de maioribus clericis de mundo. Magister cathedratus fuit Parisius et multis annis legit theologiam in domo fratrum. Optimus disputator fuit gratiosus sermocinator. Opus fecit super Sentencias. Amicus fuit regis Francie sancti Lodoici qui etiam laboravit pro eo ut archiepiscopatum Rotomagensem haberet. Ordinem fratrum predicatorum multum dilexit sicut et ordinem fratrum minorum, de quo erat et fuit eorum benefactor.'

5 P. Andrieu-Guitrancourt, in L'archevêque Eudes Rigaud et la vie de l'Eglise au XIII siècle d'après le Regestrum Visitationum (Paris: Librairie du Recueil Sire, 1938), p. 18, presumes that he entered the Franciscan order in 1236. 
of this time. ${ }^{6}$ The earliest known logician is John Pagus. Two of his works on logic survive, which reflect his teaching: the Appelationes and the Rationes super predicamenta Aristotelis. ${ }^{7}$ The little pedagogical treatise entitled De disciplina scolarium, possibly the work of the Englishman Elias of Trickingham, also designates logic as the principal discipline in the 1220 s. $^{8}$

As regards the teaching of grammar, the major figure was John of Garland, who composed some early works before 1229 . His Dictionarius, from the early 1220 s, offers a systematic explanation of words in common usage, and his De triumphis Ecclesiae, written in about 1230, is a hymn to crusade in which he refers to the strike in the University of Paris. The main body of his work dates from after 1232, when he returned to Paris following three years spent at Toulouse. ${ }^{9}$

Alongside the teaching of logic and grammar, certain masters of the liberal arts concerned themselves with moral philosophy, and with commentaries on the Ethics, the teaching of which had been authorized by the statutes of 1215. These writings reveal an indisputable connection between the teaching provided in arts and in theology, and they include allusions to the theological problems which were taught in this period. ${ }^{10}$

Teaching on the libri naturales of Aristotle remained very marginal in the 1220s, following a censure of his and related works in this area which was issued in 1210 and renewed in $1215 .{ }^{11}$ Not long after, however, a number of masters turned their attention to the commentaries of Averroes, recently translated into Latin by Michel Scot. ${ }^{12}$ Around 1225, by Gauthier's estimate, an anonymous Parisian master of arts

6 N. Gorochov, Naissance de l'université: Les écoles de Paris d'Innocent III à Thomas d'Aquin (v. 1200 - v. 1245) (Paris: Honoré Champion, 2012), pp. 381-93, and, more recently, some contributions to the collected volume, Les débuts de l'enseignement à Paris (v. 1200-v. 1245), eds. J. Verger and O. Weijers (Turnhout: Brepols, 2014).

7 A. de Libéra, 'Les Appelationes de Jean le Page,' Archives d'histoire doctrinale et littéraire du moyen âge 51 (1984), pp. 193-255; E. Franceschini, 'Giovanni Pago: Le sue Rationes super predicamenta Aristotelis e la loro posizione nel movimento aristotelico del secolo XIII,' Sophia 2 (1934), pp. 172-82, $329-50,476-86$.

8 Pseudo-Boèce: De disciplina scolarium, ed. O. Weijers (Leiden: Brill, 1976).

9 A. Grondeux, E. Marguin, 'L'œuvre grammaticale de Jean de Garlande (v. 1195-1272), auteur, réviseur, glosateur: Un bilan,' in Histoire, Epistémologie, Langage 21:1 (1999), pp. 133-63; E. MarguinHamon, L'ars lectoria Ecclesie de Jean de Garlande: Une grammaire versifiée du XIII siècle et ses gloses (Turnhout: Brepols, 2003), pp. 1-12; A. Grondeux, 'Le trivium à la faculté des arts de Paris avant 1245: Quelques questions méthodologiques,' in Les débuts de l'enseignement, eds. Verger and Weijers, pp. $65-76$.

10 Gorochov, Naissance de l'université, pp. 392-93.

11 Gorochov, Naissance de l'université, pp. 276-88, 314-15; L. Bianchi, Censure et liberté intellectuelle à l'université de Paris (Paris: Belles lettres, 1999), p. 57.

12 R.-A. Gauthier, 'Notes sur les débuts (1225-1240) du premier averroïsme,' Revue des sciences philosophiques et théologiques 66 (1982), pp. 321-74. 
composed a little treatise entitled De anima et de potenciis suis, ${ }^{13}$ which refers to Aristotle's Metaphysics and Averroes' commentary On the Soul. This proves that Michel Scot's Latin translation of Averroes was available from around this time in Paris. Apart from this brief treatise, the first quotation from Averroes in Paris is to be found in the Gloss of William of Auxerre on the Anticlaudianus of Alan of Lille $(1220-25) .{ }^{14}$

All in all, very few Parisian masters were concerned with the study of Aristotle and Averroes before 1229. The censures of 1210 and 1215 - in addition to the absence of commentaries - almost entirely silenced any teaching in Paris of Aristotle's philosophy, with the exception of works long since permitted, and even recommended by the statutes of 1215, such as the books on logic. It is in this intellectual context that Odo Rigaldus would have studied in the faculty of arts in Paris.

Around 1230, he began to frequent the Parisian schools of theology and needed to attach himself to a particular master. On the one hand, there were the more elderly masters who had been active between 1216-29: Geoffrey of Poitiers, William of Auxerre, Boniface Clutinc, Guiard of Laon, Pierre Petit, Philip the Chancellor, Matthew of Scotland, Guido of Orchellis, William of Auvergne, Arnoul of La Pierre, John of Barastre, John Blund, Peter Bar, who, declining to be converted by the first mendicant friars, all remained seculars. ${ }^{15}$ On the other hand, there were the younger masters, and their students, who gained the licencia docendi between 1226-29 and who, in certain cases, did not hesitate to join the mendicants in the course of the following years: Alexander of Hales, Nicolas of Flavigny, Stephen Bérout, William of Durham, Hugh of St Cher. ${ }^{16}$

Among the aforementioned, certain names are particularly noteworthy. The Summa aurea of William of Auxerre, written before 1223, enjoyed enormous success and conferred unparalleled prestige on its author. He stands as the pioneer of a new theology, considered as a science, which assimilated, albeit timidly, Aristotle's thinking. ${ }^{17}$ His colleague Philip the Chancellor is the author of another major theological work of the 1220s, namely, his Summa de bono, which he worked on before 1228 and which grew out of his teaching. ${ }^{18}$ It is indebted to the Summa aurea, but exhibits a more philosophical way of thinking, branching into metaphysics, psychology, and moral philosophy.

13 R.-A. Gauthier, 'Le traité De anima et de potenciis eius d'un maître ès arts (vers 1225): Introduction et texte critique,' Revue des sciences philosophiques et théologiques 66 (1982), pp. 3-55.

14 Gauthier, 'Notes sur les débuts (1225-1240) du premier averroïsme,' pp. 321-74.

15 Gorochov, Naissance de l'université, pp. 383-84.

16 Gorochov, Naissance de l'université, pp. 383-84.

17 M. Grabmann, I divieti ecclesiastici di Aristotele sotto Innocenzo III e Gregorio IX (Rome: Gregoriana, 1941), pp. 84-85; F. van Steenberghen, La philosophie au XIIIe siècle (Louvain-la-Neuve: Institut supérieur de philosophie, 1991), p. 142; J. Longère, 'Guillaume d'Auxerre,' in Dictionnaire des lettres françaises, eds. G. Grente, G. Hasenohr, and M. Zink (Paris: Fayard, 1992), p. 608.

18 Philip the Chancellor, Philippi Cancellarii Parisiensis Summa de bono, ed. N. Wicki, 2 vols (Bern: Francke, 1984). 
A third major intellectual figure in the faculty of theology in these same years was William of Auvergne, who is sometimes considered to be the first speculative theologian because of his copious use of Aristotle, notably in his Magisteriale divinale, whose composition he embarked on in $1223-24 .{ }^{19}$ To these three French theologians one must add the Englishman Alexander of Hales, a master from 1225 or 1226 onwards, whose Gloss on the Sentences of Peter Lombard dates from around 1225, between the Summa of William of Auxerre and the Summa de bono of Philip the Chancellor. Alexander of Hales was the first to write a commentary on the Sentences of Peter Lombard in the course of his magisterial lectiones. In his Glossa, theological sources predominate, among them the Bible and St Augustine, but Alexander also makes considerable use of Aristotle's writings on logic as well as his libri naturales (On the Soul, Physics, Metaphysics). ${ }^{20}$

Apart from the works of these four recognized masters, theological writings from the 1230 s appear broadly oblivious to the movement towards philosophy. ${ }^{21}$ The majority of masters perpetuated the kind of theological teaching which prevailed in the time of Stephen Langton. It is as though, as a body, the Parisian theologians were attentive to the injunctions of the Papacy, both of Honorius III and then of Gregory IX (1227-41) who, promptly after his election, addressed a letter to the Parisian masters in theology to warn them against the improper use of philosophy, Ancilla theologie. ${ }^{22}$ His discourse is in agreement with that of contemporary theologians such as Guiard of Laon, who in a sermon from the 1220s accused theologians and masters of the arts of giving clandestine teaching on 'forbidden books' ${ }^{23}$ When they were not teaching, the Parisian masters of theology also delivered many sermons, following the pattern advocated by Peter the Chanter, to an audience of students who took notes in the form of reportationes. ${ }^{24}$ Along with his fellow students, consequently, Odo Rigaldus was nourished by the preaching of these masters.

\section{The Social Context}

As a young secular student, Odo Rigaldus was immersed in an educational environment which he himself also represented, which was composed for the most part of

19 The most recent bibliography is the one compiled in Autour de Guillaume d'Auvergne (+1249), ed. F. Morenzoni and J.-Y. Tilliette (Turnhout: Brepols, 2005).

20 Alexander of Hales, Magistri Alexandri de Hales Glossa in quatuor libros Sententiarum Petri Lombardi (Quaracchi: Collegium S. Bonaventurae, 1951-57).

21 Gorochov, Naissance de l'université, pp. 385-88.

22 Gorochov, Naissance de l'université, p. 382.

23 P.C. Boeren, La vie et les œuvres de Guiard de Laon 1170-1248 (The Hague: Nijhoff, 1956), p. 159. 24 These all have an entry in J.B. Schneyer, Repertorium der Lateinischen Sermones des Mittelalters für die Zeit von 1150-1350, 11 vols (Münster: Aschendorffsche Verlagsbuchhandlung, 1969-80). 
younger sons of the minor nobility. ${ }^{25}$ In fact, Odo was the son of the lord of Courquetaine, who was based about ten kilometers from Brie-Comte-Robert, the site of the fortress of the Comte de Brie. ${ }^{26}$ Odo's elder brother, Peter, inherited the fiefdom of Courquetaine, as Odo himself reports in his account, in several passages of the Registrum, which describes the brief periods he spent at Courquetaine, in the manor house of his brother. Within this minor nobility, which often showed little interest in scholarly culture and university studies, a few families became aware early on that a period of university study could help young clerics, who were of minor noble stock, to climb up the ranks of the ecclesiastical hierarchy. It is useful to remind ourselves of the social profile of Odo's fellow students, and particularly those he mixes with in the faculty of theology in the 1230s and 1240s. Of the ninety masters, bachelors, and students in theology surveyed for the period 1231-45, more than a third came from a noble background. ${ }^{27}$ However, family ambition alone is not always a sufficient explanation for the departure of a younger son to university; such an ambition was often supported, sustained, and encouraged by a neighbouring prelate, who incited the young clerics of his diocese to go off and pursue a course of study.

On the benches of the university, the sons of squires and lords of the manor found themselves alongside clerics born into families of the high or very high nobility. Some were of illegitimate birth, for example Philip the Chancellor, son of an archdeacon of Paris related to the Nemours family, or Peter Charlot, who later became Bishop of Noyon, but who was the illegitimate son of king Philippe Auguste. ${ }^{28}$ Among them too were clerics such as Guy of Bourbon, younger son of Archambaud VI, Bourbon seigneur. ${ }^{29}$ But the highest ranked nobles undoubtedly come from Italy: Fieschi, Visconti, Anagni. From the 12th century, the great Roman families, having become 'baronial' in the 13th century, and the families of counts from Liguria or Tuscany, sent several clerics to these schools from each generation, so as to ensure their rapid entry into the curia and a career adorned with benefices. In the second quarter of the 13th century, these noble families from Italy, particularly from Latium but also from northern and central communities, developed this characteristic tendency of supporting younger sons destined for the priesthood in further studies in Paris or Bologna. ${ }^{30}$ Around $1230-40$, consequently, ten or so nobles from very powerful Italian families attended the schools of theology. ${ }^{31}$

25 Gorochov, Naissance de l'université, pp. 485-508.

26 As we learn from the Registrum: 'Apud Courquetainnes, in domo germane nostri, domini Petri Rigaudi, militis;' see T. Bonnin, Registrum visitationum Archiepiscopi Rothomagensis (Rouen: A. Le Brument, 1852), p. 313.

27 Gorochov, Naissance de l'université, p. 494.

28 Gorochov, Naissance de l'université, p. 496.

29 Gorochov, Naissance de l'université, p. 497.

30 P. Classen, 'La curia romana e le scuole di Francia nel secolo XII,' in Le istituzioni della Societas Christiana dei secoli XI-XII: Papato, cardinalato, e episcopato (Milan: Vita e pensiero, 1974), 
Finally, there were all those English nobles, of varying levels of affluence, who come together in the schools of theology in Paris: either sons of barons, like Thomas of Cantilupe, son of William, second baron of Cantilupe, or of less powerful nobles, such as Alexander of Hales, whom Roger Bacon describes as very rich (dives). ${ }^{32}$ In England, the belief in ecclesiastical circles since the 12th century was that studies were advantageous in making progress in an ecclesiastical career, and so young nobles destined for the priesthood flocked to Paris and Bologna. ${ }^{33}$

\section{The Success of the Mendicant Orders}

At the time when Odo was beginning his studies in theology, the students from the nobility were quite numerous and, if one is to believe Robert of Sorbon, ${ }^{34}$ they appear to have been particularly receptive to the discourse of the mendicant friars, perhaps because they were more affluent, and thus more attracted than others to undergo voluntary poverty. The mendicant orders were indeed spectacularly successful from the beginning of the 1230s. The Order of Preachers was established in Paris by 1218 , and Honorius III granted them a fundamental pastoral role in the university before they obtained their first chairs. ${ }^{35}$

Likewise, he encouraged the installation of the Friars Minor, commending them warmly in a letter addressed to the archbishops of Sens and the Bishop of Paris in 1219. The first friary of the minors was situated at Saint-Denis ${ }^{36}$ and numbered thirty or so friars in 1224, when the English master Haymo of Faversham, ${ }^{37}$ his companion

pp. 432-36; P. Montaubin, Le gouvernement par la grâce: La politique bénéficiale des papes au XIII siècle dans la moitié nord de la France, 2 vols, unpublished doctoral thesis (Paris: University of Paris, 1998), vol. 1, pp. 342-53.

31 For example, Federico Visconti, Hugues de Pise (Ugo de Fagiano), Ottobono Fieschi, Adénulfe d'Anagni, Jacques Savelli; see Gorochov, Naissance de l'université, pp. 497-98.

32 Gorochov, Naissance de l'université, pp. 498-500.

33 J.W. Baldwin, 'Studium et Regnum: The Penetration of University Personnel into French and English Administration at the Turn of the Twelfth and Thirteenth Centuries,' Revue des Etudes Islamiques 44 (1976), pp. 199-215; J. Barrow, 'Education and the Recruitment of Cathedral Canons in England and Germany (1100-1225),' Viator 20 (1989), pp. 117-37.

34 Gorochov, Naissance de l'université, p. 376. Robert of Sorbon's sermon is quoted in N. Bériou, L'avènement des maîtres de la parole: la prédication à Paris au XIIIe siècle, 2 vols (Paris: Institut d'études augustiniennes, 1998), vol. 1, pp. 123-24.

35 Gorochov, Naissance de l'université, pp. 366-81.

36 F. de Sessevalle, Histoire générale de l'ordre de Saint-François, vol. 1 (Paris: Editions de la Revue d'histoire Franciscaine, 1935).

37 He became provincial Minister of England in 1239-40, then Minister General of the Franciscan order in 1240; see R.B. Brooke, Early Franciscan Government (Cambridge: Cambridge University Press, 1959), pp. $202 \mathrm{ff}$. 
Simon of Sandwich, ${ }^{38}$ and two other masters of the arts joined the order. In the following months, they undertook to renovate a vast house called Vauvert, which the stricter Franciscans did not hesitate to criticize, but which collapsed just before they were able to move in. ${ }^{39}$ It is possible that the Friars Minor may have rented a house in Paris, perhaps at the top of the Mount St Geneviève, prior to the completion of the great Convent of the Cordeliers of Paris near St Germain des Prés, where they took up residence in 1230 and remained until the French Revolution. ${ }^{40}$ Their installation there was thanks to the Abbot of St Germain des Prés who gave them a plot of land, as well as to the unfailing support of William of Auvergne, Bishop of Paris $(1228-49) .{ }^{41}$ From $1230-34$ onwards, the Friars Minor occupied a vast monastery, which grew progressively year by year, situated extra muros, all along the wall of Philip Augustus. Its vast church as completed about 1260, but it housed the tombs of masters from before 1240: Philip the Chancellor had his burial there in $1236,{ }^{42}$ and Alexander of Hales in $1245 .{ }^{43}$

While the conversions of masters to the religious orders remained few in number before the end of the 1220s, the vast majority of those converts are to be found among the youngest students, those in the arts, a point on which Jordan of Saxony congratulates himself in his letters to Diane of Andalo. ${ }^{44}$ Odo Rigaldus, like the majority of masters in the arts, still held out, for some time, against joining a religious order.

\section{Odo Rigaldus, Secular and Student of Theology (c.1230-36)}

Two phases can be distinguished in the history of the schools of theology between 1230 and 1245: before 1236 - 38, the group of masters remained more or less identical to what it had been before the great strike, albeit shorn of the English masters. But then, from 1236-38 onward, significant renewals occurred, thanks to conversions. These two phases correspond to the two periods of Odo's theological studies: up

38 He became a reader in theology in the province of Saxony in 1228, according to the Chronica Fratris Jordani, ed. H. Boehmer (Paris: Fischbacher, 1908), pp. 52, 54, 58.

39 Thomas of Eccleston, Tractatus de adventu fratrum minorum in Angliam, ed. A.G. Little (Paris: Fischbacher, 1909), p. 47.

40 It grew rapidly, as has been shown by L. Beaumont-Maillet, Le Grand Couvent des Cordeliers de Paris: étude historique et archéologique du XIIIe siècle à nos jours (Paris: Champion, 1975).

41 E. Longpré, 'Guillaume d'Auvergne et l'école franciscaine de Paris,' France Franciscaine 5 (1922), pp. $426-31$.

42 Chronicum Alberici Monachi Trium Fontium, Recueil des historiens des Gaules et de la France, vol. 21, ed. J.-D. Guigniaut and N. de Wailly (Paris: Imprimerie Impériale, 1855), p. 618.

43 Chartularium Universitatis Parisiensis, eds. H. Denifle and E. Chatelain, 4 vols (Paris: Delalain Frères, 1889), vol. 1, pp. $186-87$.

44 Jordan of Saxony, Jordani de Saxonia epistulae, ed. A. Walz (Rome: Apud Institutum Historicum Fratrum Praedicatorum, 1951); see, for example, letters XXXII, XL, XLII. 
until 1236, he was a simple student, but thereafter, having become a Franciscan, he is attested as a bachelor.

\section{The Schools of Theology 1231-c.1236: The Masters}

In 1231, the theologians of the cathedral chapter of Paris, who had not gone into exile during the strike, continued their teaching in the cloister. ${ }^{45}$ Besides William of Auvergne, Bishop of Paris, who probably did no further teaching after his election (1228), the secular masters at the start of the 1230s include Philip the Chancellor (d. 1236), ${ }^{46}$ canons Odo of Chateauroux (cardinal in 1244), ${ }^{47}$ Guiard of Laon (Bishop of Cambrai in 1238), ${ }^{48}$ Pierre Petit (chancellor in 1244), ${ }^{49}$ and the Archdeacon of Paris, Stephen of Provins (d. c. 1250).$^{50}$ Beside the canons of Notre-Dame, the Dean of St Germain l'Auxerrois, Stephen Bérout, seems to have been active in the faculty of theology until his death (1243). ${ }^{51}$ Arnoul of La Pierre offered teaching in theology until his election to the bishopric of Amiens in 1236; Stephen of Cudot, who was elevated to the status of master in 1231, taught theology until he entered the Val des Ecoliers in the mid-1230s. ${ }^{52}$

It is not impossible that William of Durham, a master in theology who had gone back to England in 1229, returned to teach in Paris between 1232 and 1235 after the strike. The other master of theology who left for England during the great strike was Alexander of Hales. He returned to teach in Paris in 1231 or 1232, despite having been endowed with several ecclesiastical benefices in England, including a prebend at St Paul's in London, a prebend at Lichfield and the archdeaconate of Coventry. ${ }^{53}$ Having been settled in Paris for more than twenty years, this master, already highly reputed and with an excellent knowledge of the Capetian kingdom, was entrusted by King Henry III of England on 25 August 1235 with the mission of serving as his representative to King Louis IX to negotiate a truce. Already in his fifties, Alexander of

45 A.-L. Gabriel, 'Les écoles de la cathédrale de Notre-Dame et le commencement de l'université de Paris,' Revue d'histoire de l'Eglise de France 50:147 (1964), pp. $73-98$.

46 P. Glorieux, Répertoire des maîtres en théologie de Paris au XIII siècle, 2 vols (Paris: J. Vrin, 1933), vol. 1, pp. 282-84.

47 A. Charansonnet, 'Du Berry en Curie: la carrière du cardinal Eudes de Châteauroux (1190? - 1273),' Revue d'histoire de l'Eglise de France 86 (2000), pp. 5-37.

48 Boeren, La vie et les œuvres de Guiard de Laon.

49 Glorieux, Répertoire des maîtres, vol. 1, p. 312.

50 Glorieux, Répertoire des maîtres, vol. 1, p. 303.

51 A. Molinier, Obituaires de la province de Sens (Paris: Imprimerie Nationale, 1902), vol. 1, pp. 446, 502, 794.

52 Glorieux, Répertoire des maîtres, vol. 1, p. 321; C. Guyon, Les écoliers du Christ: L'ordre canonial du Val des Ecoliers 1201-1539 (Saint-Etienne: CERCOR, 1998), p. 523.

53 On William of Durham and Alexander of Hales, see Gorochov, Naissance de l'université, pp. 462-64. 
Hales seemed then close to the peak of his ecclesiastical career: in 1235, all he lacked was the rank of bishop.

Besides these ten secular schools whose masters, with the exception of Stephen of Cudot, were all in possession of their chairs by 1229, there were also, in the aftermath of the great strike, the two schools acquired by the Dominicans between 1229 and 1231: the school created by the Bishop of Paris for Roland of Cremona (1229), which he left to Hugh of St Cher on his departure to Toulouse, and the school of John of St Giles, which came into the possession of the Preachers when this secular master entered the order in 1230. Promoted to the rank of Prior Provincial in 1233, Hugh of St Cher was called on to travel, and he let his chair, sometimes called the 'chair of the French', to Stephen of Vénizy (1233-35), who is succeeded by Geoffrey of Bléneau (1235-42), while the other chair of the convent of St Jacques passed in 1233 to Guerric of St Quentin (1233-42), a pupil of John of St Giles who departed for Toulouse to replace Roland of Cremona who had returned to Italy. ${ }^{54}$ In all, a dozen masters of theology, or maybe thirteen if, like Palémon Glorieux, one includes Peter of Bar, who preached in Paris between 1229 and 1231, but who is otherwise not attested as a master. In 1229, therefore, a dozen schools of theology, rather than sixteen or seventeen, and these masters of theology, all originated from the kingdom of France, with the exception of two Englishmen, William of Durham and Alexander of Hales, after the departure of John of St Giles. ${ }^{55}$ Most probably, Odo Rigaldus studied under Alexander of Hales, as did John of La Rochelle and other fellow students, at a time when the theology faculty was in the throes of an important debate.

\section{The Argument over Plurality of Benefices (1235-38)}

In the course of the year 1235, all these masters of theology, both seculars and regulars, were called together by the Bishop of Paris, William of Auvergne, to debate the plurality of benefices. ${ }^{56}$ This was an argument which caused disturbance in the theological schools between 1235 and 1238. The austere bishop sought to oppose the practice of accumulating benefices, which he condemned in a treatise entitled $D e$ collatione beneficiorum where he inveighs against those who do so in the most vehe-

54 Gorochov, Naissance de l'université, p. 464.

55 Gorochov, Naissance de l'université, p. 464.

56 As the Dominican Thomas de Cantimpré testifies in a passage of Bonum universale de apibus, ed. Denifle in the Chartularium Universitatis Parisiensis, vol. I, pp. 157-58; see also C. de Miramon, 'La place d'Hugues de Saint-Cher dans les débats sur la pluralité des bénéfices (1230 - 1240),' in Hugues de Saint-Cher (+1263): Bibliste et théologien, eds. L.-J. Bataillon, G. Dahan, and P.-M. Gy (Turnhout: Brepols, 2004), pp. 341-86. 
ment terms. ${ }^{57}$ The stance adopted by the Bishop of Paris must be seen in the context of a debate whose origins go back some two or three decades to the development of pluralism itself, and which became one of the main debates troubling the church in the 13 th century.

At the time, everyone ended up taking one side or the other in the argument. ${ }^{58}$ In sermons from the year 1230 -31, for example, several masters criticized the plurality of benefices as well as the clerics who, in the hope of climbing the social ladder, prolonged their studies repeatedly, abandoning their flock to the care of incompetent curates. ${ }^{59}$ Guiard of Laon was one of the first, alongside William of Auvergne, to preach against the accumulation of benefices. John of St Giles, Odo of Châteauroux, and some unnamed Dominicans also preached against this practice in the weeks following. Theirs represented a kind of coordinated attack, launched using the same arsenal of weapons, that is, the same biblical references, from one sermon to the next.

Both in France and in England, in contested episcopal elections, the controversy over accumulation was even invoked as a reason to reject a particular candidate, and no one could afford to ignore this debate, nor the pontifical stance on pluralism. ${ }^{60}$ William of Auvergne thus aroused a long and solemn dispute in which the masters, with the exception of Philip the Chancellor and Arnoul of La Pierre, took a stand against the pluralism of benefices. They ruled that there can be no possible salvation for any holder of two benefices, either one of which yields a revenue of fifteen livres parisis or more, and that this verdict must be disseminated by the masters within their schools. In 1238, William of Auvergne once more called together the masters of theology and renewed this verdict, condemning the accumulation of benefices. According to Thomas of Cantimpré, who was apparently present at the debate, the Bishop of Paris had emerged victorious as early as 1235, since the majority of the masters, with the exception of two, had declared themselves opposed to such pluralism.

These university debates on the pluralism of benefices, along with the verdict of the Bishop of Paris promulgated in 1235 and renewed in 1238, had an impact both within the University of Paris and also beyond the limits of the university environment. At the French royal court, for instance, King Louis IX himself began to apply this principle of non-accumulation, according to the chronicler Geoffrey of Beaulieu. ${ }^{61}$ In 1237, moreover, the debate crossed the Channel, where it was brought to England by the legate Otton of Tonengo, who, in the Council which he convened in London in November 1237, fully intended to have drafted lengthy reforming statutes,

57 William of Auvergne, De collatione beneficiorum, Opera Omnia (Paris-Orléans: Lacaille, 1671), vol. 2, p. 248-60; see also N. Valois, Guillaume d'Auvergne, évêque de Paris (1228-1249): Sa vie et ses ouvrages (Paris: A. Picard, 1880), pp. 28-39.

58 Gorochov, Naissance de l'université, pp. 465-79.

59 Bériou, L'avènement des maîtres de la parole, pp. 122, 159. Eudes de Châteauroux is also an avowed opponent of the accumulation of benefices.

60 C. de Miramon, 'La place d'Hugues de Saint-Cher dans les débats.'

61 Valois, Guillaume d'Auvergne, évêque de Paris, pp. 28-39. 
including the prohibition of the accumulation of benefices and the sharing of prebends. ${ }^{62}$

At the request of several prelates, however, the legate shifted to a more moderate position. The restraint shown by legate Otton was also due to the fact that the English reforming prelates who opposed pluralism had little to say at the Council of London, as was the case with Edmond, Archbishop of Canterbury, and Robert Grosseteste, Bishop of Lincoln, who was apparently unwell at the time of the Council. ${ }^{63}$ So it is that, in both the university and the diocese of Paris, and on the other side of the channel, despite divisions of opinion among the clergy, the accumulation of ecclesiastical benefices was increasingly frowned upon. Through sermons, disputationes, and councils, opposition to pluralism found insistent expression in both university debates and in ecclesiastical legislation. Could 'pluralist' clerics continue to ignore the criticisms and threats of damnation emerging from Paris, London, Oxford and the Curia? This atmosphere had the effect of spurring the masters and their bachelor students into resigning some of their benefices, or even renouncing them entirely to enter the ranks of the canon regulars. Conversions increased in number between 1236 and 1238. For his part, Odo Rigaldus chose to join the Franciscans.

\section{Odo Rigaldus as Franciscan, Bachelor, and Master of Theology (c.1236-48)}

\section{The Conversion of Odo and Others after the Debate on the Plurality of Benefices}

Among the most renowned cases of conversion, two of the most conspicuous Parisian masters at that time, Alexander of Hales, master of theology, and Richard Rufus of Cornwall, master of arts, chose to join the Friars Minor in Paris, in the period between 1236 and 1238. These dates coincide strikingly with the debate on pluralism. Alexander of Hales took several of his pupils with him following his conversion, notably Odo Rigaldus, who had up to that point remained a secular student, and who himself took the Franciscan habit shortly after his master, in the same year $1236 .{ }^{64}$ A few years later, Bonaventure decided to enter the Franciscan order, reportedly out of admiration for his old master Alexander of Hales, and this was also the case for the theology graduate Raoul of Corbrigge. ${ }^{65}$

62 D.M. Williamson, 'Some Aspects of the Legation of Cardinal Otto in England, 1237-1241,' English Historical Review 64 (1949), pp. 145-73.

63 Williamson, 'Some Aspects of the Legation of Cardinal Otto in England,' p. 162.

64 Andrieu-Guitrancourt, L'archevêque Eudes Rigaud, p. 18.

65 A.B. Emden, A Biographical Register of the University of Oxford to 1500, 3 vols (Oxford: Oxford University Press, 1957), vol. 1, p. 484. 
Upon joining the order in 1236, Alexander of Hales became the second master of theology in Paris to join the mendicants, following John of St Giles in $1230 .{ }^{66} \mathrm{Al}$ though Alexander's decision to join the order was partly due to an admiration for Franciscan spirituality, it is impossible to say whether he was also motivated by a desire to leave behind the complex situation as regards benefices, which were frowned upon by the ecclesiastical authorities, or perhaps by an inclination often found in elderly clerics to end their days in a monastic community. Be that as it may, his conversion in 1236 gave the Friars Minor a chair in theology in Paris and marked the inauguration of a 'Franciscan school' for disciples of St Francis wishing to study theology.

Further conversions occurred in schools of theology other than that of Odo Rigaldus, and these too were perhaps linked to the climate of hostility towards the accumulation of benefices. Stephen of Cudot, master of theology from 1230/31, left the schools at the end of the 1230 s to join the Val des Ecoliers. ${ }^{67}$ The conversion of Richard Rufus of Cornwall was another that cannot have passed unnoticed in Parisian school circles. By the time he joined the Franciscans in Paris in 1238, less than two years after Alexander of Hales and Odo Rigaldus, Richard Rufus was a renowned master, a pioneer in the teaching of the Physics and the Metaphysics of Aristotle in Paris. $^{68}$

In England, at exactly the same time, the conversions of some very highly-placed clerics in the episcopal hierarchy must have had an impact on their contemporaries. The rising opposition to pluralism, accompanied by forceful encouragements to resign benefices for which residence was not a requirement, pressured masters and students, including ambitious and well-supported clerics, to devote themselves fully to pastoral duties in a single benefice, unless they entered the Franciscan order.

\footnotetext{
66 Emden, A Biographical Register of the University of Oxford, vol. 3, p. 2180.

67 See Molinier, Obituaires de la province de Sens, vol. 1, pp. 446, 502, 794.

68 The life and works of Richard Rufus have given rise to an extensive bibliography and debate, both as regards the chronology of his writings and their attribution. P. Raeds, Richard Rufus of Cornwall and the Tradition of Oxford Theology (Oxford: Clarendon Press, 1987), adds to knowledge about Richard Rufus, but questions the authenticity of Rufus' commentary on the Metaphysics. On this point, he has been criticized by T. Noone, 'Richard Rufus of Cornwall and the Authorship of the Scriptum super Metaphysicam,' Franciscan Studies 49 (1989), pp. 55-91, and also by R. Wood, who demonstrated the ground-breaking nature of Rufus' teaching on the Physics and the Metaphysics in Paris before 1238, in particular in Richard Rufus of Cornwall, In Physicam Aristotelis (Oxford: Oxford University Press for The British Academy, 2003). The entry which Emden, at an earlier date, devoted to Rufus in A Biographical Register of the University of Oxford, vol. 3, pp. 1604-5, gives an incorrect date for his conversion.
} 


\section{The Schools of Theology (1236-45)}

After 1236-38, following the disturbances provoked by the debate over the plurality of benefices, a change took place amongst the masters of theology in Paris. Alexander of Hales pursued his teaching in the convent of the Friars Minor. When, nine years later, on 15 August 1245, Alexander died in Paris, the passing of this renowned master of theology had a very wide impact. ${ }^{69}$ The masters of theology active in the years 1235-45 included the seculars Aymeric of Veyre, Peter of Lamballe, Gauthier of Château-Thierry, Stephen of Poligny, Jacques of Dinant, and John Pagus, and after 1245, Raoul of Montdidier, William of Cramaut, Peter the Archbishop, and Adam of Pouzzoles. To these should perhaps be added the name of Raoul of Corbrigge, assuming that he was already a master when, influenced by Alexander of Hales, he joined the Franciscans between 1240 and $1245 .^{70}$ Teaching at the convent of St Jacques were Geoffrey of Bléneau, Laurent of Fougères and William of Etampes, holders of the first Dominican chair, and Guerric of St Quentin and Albert the Great, holders of the second chair. ${ }^{71}$ At the Franciscan convent, Alexander of Hales may have passed his chair on to his disciple John of La Rochelle in 1238, who was succeeded by Odo Rigaldus, who gained the status of master in $1245 .^{72}$

Almost all these names are to be found in the Latin MS 15652 in the Bibliothèque Nationale de France, within the notes taken down by an anonymous student in the course of lessons on the Sentences or the Bible, which were delivered in Paris around 1240. This studious author seems to have taken notes for two or three years in succession. ${ }^{73}$ These reportationes, all in the same hand, occupy folios $32-80$ and $81-$ 109 of the manuscript, which also contains notebooks in other formats and by other hands. These notes taken down from lessons given by bachelor students of the Sentences are followed, in folios $110-221$, by notes similarly constructed from the lessons given by masters on the Bible.

In the view of M.-D. Chenu, despite some differences in format, the collection is manifestly homogeneous in nature and offers an account of various commentaries by masters of the Bible. ${ }^{74}$ These notes naturally reflect the forms of teaching current in the theology faculty in the early 1240s, with commentary on the Bible by the masters and commentary on the Sentences by the bachelors, a demarcation which was beginning to become established. The manuscript also includes reportationes on questions, in particular in folios 11-13 and 107-9. This manuscript and works written in this same period shed light on the conditions in which this literature was born, and allow us to identify the masters, often accompanied by disciples, who drew

69 Gorochov, Naissance de l'université, p. 479.

70 Gorochov, Naissance de l'université, p. 479.

71 Glorieux, Répertoire des maîtres en théologie, vol. 1, pp. 42-82.

72 Chenu, 'Maîtres et bacheliers.'

73 Chenu, 'Maîtres et bacheliers.'

74 Chenu, 'Maîtres et bacheliers.' 
up the major works. The name of Odo Rigaldus appears on folio 32, where the scribe has noted down the 'introitus', i.e. his first lesson as a bachelor on the Sentences, a text which remains unpublished to this day.

\section{Odo Rigaldus in the School of Alexander of Hales: The 'Scholastic Workshop'}

In the years of 1236 - 45, Odo Rigaldus was a member of the school, which gathered around the master 'mourned by the whole university, ${ }^{, 75}$ Alexander of Hales, a secular until 1236 and then a Franciscan from 1236 to 1245. Even before the great strike, the bachelor Alexander of Hales had composed commentary on the Sentences of Peter Lombard, ${ }^{76}$ inaugurating a form of teaching which was to become more common from the 1240s onwards, and which became the preserve of bachelors. The teaching of Alexander of Hales, enshrined in the form of theological questions, is relatively little known, in particular, the questions following his conversion. ${ }^{77}$ Until 1236, the assumption was that this secular master enjoyed a great reputation and that he attracted many pupils.

Within Alexander's circle of pupils, alongside Odo Rigaldus, was John of La Rochelle, who joined the Friars Minor around 1230. After obtaining his 'licence' degree in theology, John of La Rochelle seems to have headed a second Franciscan school from 1238 to 1245, unless in fact he took over the chair of Alexander, who apparently did not undertake regular teaching after 1238; opinions vary on this point. ${ }^{78}$ What is definite, however, is the major role which John played in the composition of the Summa Halensis, which was for a long time attributed to Alexander of Hales alone. Many publications have shown that the first and third parts of the Summa, begun around 1240, are from the hand of John of La Rochelle rather than exclusively that of Alexander, and that the second part was written by another, unnamed, disci-

\footnotetext{
75 John of Garlande, De triumphis Ecclesie, cited in Gorochov, Naissance de l'université, p. 479.

76 This text was only discovered in 1945; see F.-M. Henquinet, 'Le commentaire d'Alexandre de Halès sur les Sentences enfin retrouvé,' in Miscellanea Giovanni Mercati, vol. 2 (Vatican City: Biblioteca Apostolica Vaticana, 1946), pp. 359-82.

77 Only the questions preceding his conversion have been published: Alexander of Hales, Magistri Alexandri de Hales Quaestiones disputatae "Antequam esset frater”, 3 vols (Quaracchi: Collegium S. Bonaventurae, 1960).

78 The existence of a second Franciscan school is the subject of discussion in several articles. For instance, according to H. Felder ('Les franciscains ont-ils eu deux écoles universitaires à Paris de 1238 à 1253?' Etudes Franciscaines 25 [1911], pp. 598-613), Alexander of Hales obtained a second chair for the benefit of his pupil John of La Rochelle. P. Glorieux (Répertoire des maîtres en théologie, vol. 2, p. 25) takes a different view, that John of La Rochelle obtained Alexander of Hales' chair in about 1238.
} 
ple. ${ }^{79}$ Nevertheless, these two authors make abundant use of the writings of Alexander, sometimes to present his doctrine and at other times to contradict it. ${ }^{80}$

The second author of the Summa, a Parisian Franciscan from the 1240s, has not been definitively identified, and a series of names have been proposed as possibilities: Robert of La Bassée, Bertrand of Bayonne, John of Parma, or Odo of Rosny, all of whom were students of theology in the convent of the Friars Minor between 1230 and 1245. ${ }^{81}$ Specialists have declined to detect in the opening parts the hand of the Englishman William of Melitona, another of Alexander's pupils, who was however given official responsibility for the completion of the fourth volume of Summa on the sacraments in $1256 .{ }^{82}$ According to Salimbene, John of Parma offered a commentary on the Sentences when he was a bachelor, dating to around 1240, probably under the authority of Alexander of Hales. ${ }^{83}$ He then went on to teach at Bologna and Naples, before being promoted to Minister General of the Order in 1247. Shortly before 1245, Bonaventure came to Paris to study theology, and presumably was a pupil of Alexander of Hales; he did not become a bachelor until 1248.

Alain Boureau invented the term 'scholastic workshop' to describe the school of Alexander of Hales, a workshop based on the principle of a division of labor according to the skills each had acquired. In the case of the Summa, there is no feature which serves to distinguish the various authors, who have only been identified by specialists patiently scrutinizing the text. ${ }^{84} \mathrm{~A}$ further collective work prepared in 1242 in the 'scholastic workshop' around Alexander of Hales was the Expositio regulae quattuor magistrorum, published under Alexander's own name, and the names of those who were no doubt his three closest disciples, John of La Rochelle (master), Odo Rigaldus and Robert of La Bassée (both bachelors). ${ }^{85}$

F.-M. Henquinet emphasized years ago the influence which Odo Rigaldus exercised, not only on Franciscan students such as Bonaventure, Odo de Rosny, and Adam of Pouzzoles, who were studying alongside him, but also on the Friars Preachers, such as Albert the Great, who had occasion to hear him or read his work. ${ }^{86}$ The

79 F.-M. Henquinet, 'Frater Considerans, l'un des auteurs jumeaux de la Summa Fratris Alexandri primitive,' Recherches de théologie ancienne et médiévale 15 (1948), pp. 76-96.

80 Alexander of Hales, Doctoris irrefragabilis Alexandri de Hales Ordinis minorum Summa theologica, 4 vols (Quaracchi: Collegium S. Bonaventurae, 1924-48); see the Prolegomena in volume IV.

81 In his article, 'Frater Considerans, l'un des auteurs jumeaux de la Summa Fratris Alexandri primitive,' F.-M. Henquinet suggests instead the name of Robert de La Bassée.

82 R. Sharpe, A Handlist of the Latin Writers of Great Britain and Ireland before 1540 (Turnhout: Brepols, 2001), pp. 789-91.

83 Salimbene, Chronica, vol. 1, p. 434.

84 A. Boureau, L'empire du livre: Pour une histoire du savoir scolastique, 1200-1380 (Paris: Belles lettres, 2007), p. 41; also V. Doucet, 'Prolegomena in librum III necnon in libros I et II Summae Fratris Alexandri,' in Alexandri de Hales Summa theologica (Quaracchi: Collegii S. Bonaventurae, 1948).

85 Expositio, ed. Oliger.

86 F.-M. Henquinet, 'Les manuscrits et l'influence des écrits théologiques d'Eudes Rigaud O.F.M.' Revue de théologie ancienne et médiévale 11 (1939), pp. 324-50. 
passage from the Chronique of Salimbene similarly lays bare the close relations between the preachers and minor theologians at the time of Odo's tenure of the office of Regent $(1245-48){ }^{87}$

\section{Theological Teaching and Preaching in the Period 1231-45}

From the 1230s onward, there was an upsurge in preaching in the University of Paris, closely linked to the teaching of theology. ${ }^{88}$ In addition to their lectures and 'scholastic workshops', Odo Rigaldus and his fellow students and masters probably devoted a considerable proportion of their time to this activity. Increased opportunities for preaching also came with the introduction of the 'collation' or afternoon sermon, which added further commitments to an already heavy preaching schedule. Between 1230 and 1245, sermons were more or less equally shared between seculars and mendicants, as the masters of theology in Paris continued to be very active preachers in this period.

Whether seculars or mendicants, Parisian theologians practiced as a matter of course the new art of preaching, the sermo modernus, which is already attested in the first third of the 13th century and which flourished after 1230-31, as Nicole Bériou has shown in her research. ${ }^{89}$ The many Artes predicandi written by the Parisian masters now emphasized the task of composition, based on subdividing and expanding on the theme. On Sundays and feast-days, students could regularly listen to sermons given by masters or bachelors of theology, seculars or mendicants, which they could then take as models to emulate in other contexts.

The chronicler Salimbene powerfully underlines Odo Rigaldus' qualities as a preacher. Sources testify that he preached a hundred sermons, and yet, up until now, only eight extant sermon texts can be attributed to Odo Rigaldus with any certainty. ${ }^{90}$ Of these eight, two might be said to originate from sermons preached in the University of Paris; one, unpublished, was delivered on the occasion of the feast of St Nicholas on 6 December 1242, when Odo was a bachelor student of the Sentences, ${ }^{91}$ while the other, undated, is a sermon for St Catherine..$^{92}$ In all probability, it was to

87 See the passage from Salimbene quoted at the beginning of this study.

88 Bériou, L'avènement des maîtres de la parole, especially vol. 1, pp. 109-12 and pp. 147-214; L.-J. Bataillon, 'De la lectio à la predicatio: Commentaires bibliques et sermons au XIII ${ }^{\mathrm{e}}$ siècle,' Revue des sciences philosophiques et théologiques 70 (1986), pp. 559-74.

89 Bériou, L'avènement des maîtres de la parole, vol. 1, p. 114.

90 On the preaching of Odo Rigaldus in general, see S. Delmas, 'Eudes Rigaud prédicateur,' Collectanea Franciscana 83 (2013), pp. 1-12.

91 This is known from two manuscripts: Paris, Bibliothèque nationale de France, lat. 16502, fols 157r158r, and Brussels, KBR, II, 1142, fol. 134, according to J.-B. Schneyer, Repertorium, vol. IV, p. 511. 92 J.-G. Bougerol, 'Un sermon inédit d'Eudes Rigaud,' Archives d'histoire doctrinale et littéraire du Moyen Age 62 (1995), pp. 343-58. 
the most talented bachelors and masters, including Odo, that the university entrusted the preaching for these two great feast days of the corporation.

\section{Conclusion}

The foregoing study inevitably casts more light on the milieu of the University of Paris in the years 1220-40 than it does on the personal career of Odo Rigaldus, which is very poorly documented. Nevertheless, what emerges is that Odo was a man of his time and that he held very much in common with his contemporaries. There is nothing to suggest that he had a particular interest in the newly available treatises of Aristotle, and he shows similar prudence in the face of the success of the mendicant orders among younger students in the schools. Odo was a secular student, and probably attached himself very early on to a secular master.

From the start of his studies in theology, that master may well have been Alexander of Hales, one of the most prominent masters in Paris around 1230. Later on, in 1236, their almost simultaneous choice to enter the Franciscan order seems like no mere coincidence, following as it does on the bitter debate over the plurality of benefices. This context however in no way precludes the spiritual dimension of their conversion. Many other examples can be found of such simultaneous conversions of masters and disciples. ${ }^{93}$ After becoming a bachelor, Odo taught in the monastery of the Friars Minor, and participated in the collective works produced in the scholastic workshop, teaching the younger members, and Bonaventure in particular.

After his election as Archbishop of Rouen in 1248, Odo Rigaldus, who was trained at the highest levels in liberal arts and in theology, did not break from his previous life as a master of theology in the monastery of the Friars Minor. He retained a strong memory of his former masters and fellow students whose names appear occasionally in the Regestrum. One such name is that of Thomas Hélie of Biville, who studied theology at the same time as Odo Rigaldus, between 1230 and 1240, and to whose tomb Archbishop Odo went to pay his respects in $1266 .{ }^{94}$ Among those closest to him include former Parisian masters who, by chance or by design, obtained a prebend in Rouen. ${ }^{95}$ The history of these networks of relationships forged in the schools of Paris in the 13th century still remains to be written.

93 N. Gorochov, 'Les écoles et les relations entre maîtres et étudiants dans l'université de Paris au XIII siècle,' in L'enseignement supérieur dans les mondes antiques et médiévaux, ed. H. Hugonnard-Roche (Paris: Vrin, 2008), pp. 43-68.

94 Bonnin, Registrum, p. 555.

95 For example, see Gui of Bourbon, fellow student of Odo Rigaldus, who was canon and dean of the cathedral chapter at Rouen when Odo was archbishop, in the early 1260s; see Gorochov, Naissance de l'université, p. 497. 